Original Article

\title{
Mechanisms of oxidative stress-induced in vivo mutagenicity by potassium bromate and nitrofurantoin
}

\author{
Takuma Tsuchiya1,2, Aki Kijima1, Yuji Ishii1, Shinji Takasu, Yuh Yokoo¹, Akiyoshi Nishikawa1, \\ Tokuma Yanai², and Takashi Umemura1, 3* \\ ${ }^{1}$ Division of Pathology, National Institute of Health Sciences, 3-25-26 Tonomachi, Kawasaki-ku, Kawasaki-shi, Kanagawa 210-9501, \\ Japan \\ ${ }_{2}^{2}$ Pathogenetic Veterinary Science, United Graduate School of Veterinary Sciences, Gifu University, 1-1 Yanagido, Gifu-shi, Gifu \\ 501-1193, Japan \\ ${ }^{3}$ Department of Animal Nursing, Yamazaki Gakuen University, 4-7-2 Minamiosawa, Hachioji-shi, Tokyo 192-0364, Japan
}

\begin{abstract}
Oxidative stress is well known as a key factor of chemical carcinogenesis. However, the actual role of oxidative stress in carcinogenesis, such as oxidative stress-related in vivo mutagenicity, remains unclear. It has been reported that 8-hydroxydeoxyguanosine $(8-\mathrm{OHdG})$, an oxidized DNA lesion, might contribute to chemical carcinogenesis. Potassium bromate $\left(\mathrm{KBrO}_{3}\right)$ and nitrofurantoin (NFT) are known as renal carcinogens in rats. Our previous studies showed an increase in mutant frequencies accompanied by an increased level of 8-OHdG in the kidneys of rodents following $\mathrm{KBrO}_{3}$ or NFT exposure. Furthermore, $\mathrm{KBrO}_{3}$ and NFT induced different types of gene mutations. Thus, in the present study, we performed reporter gene mutation assays and 8-OHdG measurements following $\mathrm{KBrO}_{3}$ or NFT exposure using $\mathrm{Nrf2}$-proficient and $\mathrm{Nrf2}$-deficient mice to clarify the relationship between $\mathrm{KBrO}_{3}$ - or NFT-induced oxidative stress and subsequent genotoxicity. Administration of $1,500 \mathrm{ppm}$ of $\mathrm{KBrO}_{3}$ in drinking water resulted in an increase in deletion mutations accompanied by an increase in $8-\mathrm{OHdG}$ level, and administration of 2,500 ppm of NFT in diet induced an increase in guanine base substitution mutations without elevation of the 8-OHdG level in $\mathrm{Nrf2}$-deficient mice. These results demonstrated that the formation of 8-OHdG, which resulted from the oxidizing potential of $\mathrm{KBrO}_{3}$, was directly involved in the increase in deletion mutations, although factors related to oxidative stress other than 8-OHdG might be crucial for NFT-induced guanine base substitution mutations. The present study provides new insight into oxidative stress-related in vivo mutagenicity. (DOI: 10.1293/tox.2018-0024; J Toxicol Pathol 2018; 31: 179-188)
\end{abstract}

Key words: bromates, nitrofurantoin, NF-E2-related factor 2, DNA damage, mutagens, kidney

\section{Introduction}

The formation of reactive oxygen species (ROS) is considered one of the key factors in chemical carcinogenesis. However, the actual role of oxidative stress remains unclear. Some reports suggest that ROS play an important role in the promotion of chemical carcinogenesis by stimulating the proliferation of initiated cells ${ }^{1-3}$, while others demonstrate that ROS might be an initiator by forming oxidized DNA lesions $^{1,4-6}$. 8-Hydroxydeoxyguanosine (8-OHdG) is the most abundant oxidized DNA lesion among the many oxidized nucleosides known and is fairly stable? ${ }^{7}$ Repair of $8-\mathrm{OHdG}$ is carried out by the base excision repair enzymes. In humans,

Received: 9 April 2018, Accepted: 26 April 2018

Published online in J-STAGE: 2 June 2018

*Corresponding author: T Umemura (e-mail: umemura@nihs.go.jp)

(C)2018 The Japanese Society of Toxicologic Pathology

This is an open-access article distributed under the terms of the Creative Commons Attribution Non-Commercial No Derivatives (c) $($ (by-nc-nd) License. (CC-BY-NC-ND 4.0: https:// (cC)
OGG1, MUTYH, and MTH1 repair 8-OHdG and contribute to the protection of genomic DNA from oxidative stress8. The remaining $8-\mathrm{OHdG}$ is considered to cause $\mathrm{G}: \mathrm{C}$ to $\mathrm{T}: \mathrm{A}$ transversions by mispairing with adenine and $8-\mathrm{OHdG}^{9}, 10$.

Potassium bromate $\left(\mathrm{KBrO}_{3}\right)$ induces renal cell tumor formation in $\mathrm{F} 344$ rats and has been classified as a genotoxic carcinogen because of positive mutagenicity in the Ames ${ }^{11}$, chromosome aberration ${ }^{12}$, and micronucleus tests ${ }^{13}$. Studies demonstrating induction of $8-\mathrm{OHdG}$ by $\mathrm{KBrO}_{3}$ in vitro and in vivo suggest that 8-OHdG plays a key role in $\mathrm{KBrO}_{3}$ mutagenesis and carcinogenesis ${ }^{14-17}$. It was reported that $\mathrm{KBrO}_{3}$ produces bromine radicals, which oxidize guanine bases ${ }^{18}$. Additionally, our previous study using a two-stage rat renal carcinogenesis model clarified the in vivo mutagenicity and initiation following induction of an oxidized DNA lesion in the kidneys of rats administered $\mathrm{KBrO}_{3}{ }^{19}$ and showed that high amounts of $8-\mathrm{OHdG}$ resulted in several types of mutations, including deletion mutations, in addition to G:C to T:A transversions ${ }^{19}$. The antimicrobial compound nitrofurantoin (NFT) is also known as a renal carcinogen in rats and is prohibited for veterinary use in $\operatorname{Japan}^{20}$. The reduction of the nitro group of NFT induces oxidative stress, 
which exerts antibacterial activity ${ }^{21-23}$. Moreover, the involvement of oxidative stress is suspected in NFT-induced carcinogenesis. In fact, our recent study showed increased levels of 8-OHdG and gpt mutant frequencies (MFs) with guanine base substitution mutations, including $\mathrm{G}: \mathrm{C}$ to $\mathrm{T}: \mathrm{A}$ transversions, in the kidneys of gpt delta rats treated with $\mathrm{NFT}^{24}$. Nonetheless, the relationship between the formation of 8-OHdG and several types of mutations, including deletion mutations and G:C to T:A transversions, remains unclear.

One of the redox-sensitive transcription factors, nuclear factor erythroid 2-related factor 2 (NRF2), regulates cellular responses to oxidative stress by transactivation of antioxidant response element (ARE)-bearing genes encoding antioxidant-related enzymes, such as $\mathrm{NAD}(\mathrm{P}) \mathrm{H}$ :quinone oxidoreductase 1 (NQO1), heme oxygenase 1 (HO1), and glutathione S-transferase (GST) 25,26 . Because of the function of NRF2, Nrf2-deficient mice show higher sensitivity to various toxicants that induce oxidative stress ${ }^{27-31}$; therefore, these mice are quite suitable for investigation of the involvement of oxidative stress in chemical-induced genotoxicity and carcinogenesis.

In the present study, $\mathrm{Nrf2}$-proficient and $\mathrm{Nrf2}$-deficient mice were exposed to $\mathrm{KBrO}_{3}$ in drinking water or NFT in diet for 4 and 13 weeks and then subjected to reporter gene mutation assays ${ }^{32,33}$ and measurement of $8-\mathrm{OHdG}$ levels in the kidney DNA to clarify the relationship between the formation of 8-OHdG and several types of mutations. In addition, the study aimed to elucidate the detailed mechanism of oxidative stress involvement in $\mathrm{KBrO}_{3}$ - or NFT-induced renal carcinogenesis.

\section{Materials and Methods}

\section{Chemicals}

Potassium bromate (MW 167, CAS No. 7758-01-2) and NFT $\left(\mathrm{C}_{8} \mathrm{H}_{6} \mathrm{~N}_{4} \mathrm{O}_{5}\right.$, MW 238.2, CAS No. 67-20-9) were purchased from Wako Pure Chemical Industries (Osaka, Japan) and Sigma-Aldrich (St. Louis, MO, USA), respectively.

\section{Animals, diet, and housing conditions}

The study protocol was approved by the Animal Care and Utilization Committee of the National Institute of Health Sciences. Nrf2-deficient mice with the C57BL/6J background established by Itoh et al. ${ }^{34}$ were crossed with gpt delta mice with the C57BL/6J background (Japan SLC, Shizuoka, Japan). $\mathrm{Nrf}^{2^{-/}} \mathrm{gpt}$ delta mice and $\mathrm{Nrf2^{+/+ }} \mathrm{gpt}$ delta mice were then obtained from the F1 generation and genotyped by polymerase chain reaction (PCR) with DNA taken from the tail of each mouse. All mice were housed in polycarbonate cages ( 3 to 5 mice per cage) with hardwood chips for bedding in a conventional animal facility maintained at a controlled temperature $\left(23 \pm 2^{\circ} \mathrm{C}\right)$ and humidity $(55 \pm 5 \%)$, with 12 air changes per hour and a 12-h light/ dark cycle. Mice were given free access to CRF-1 basal diet (Charles River Laboratories Japan, Kanagawa, Japan) and tap water.

\section{Experimental design}

Six-week-old male mice of each genotype were divided into six groups (four to eight mice per group). $\mathrm{KBrO}_{3}$ was dissolved in distilled water at concentration of 1,500 ppm, and the prepared water was given to the animals $a d$ libitum for 4 or 13 weeks. NFT was mixed in CRF-1 basal diet at concentration of 2,500 ppm, and the prepared diet was given to the animals ad libitum for 4 or 13 weeks. Mice of the control group were given distilled water and CRF-1 basal diet. Dose levels of $\mathrm{KBrO}_{3}$ and NFT were selected as each maximum dose that could be administrated to mice for 13 weeks based on a report of intestinal carcinogenesis in $\mathrm{Nrf}^{-/-}$mice ${ }^{27}$, a subacute toxicity study of $\mathrm{KBrO}_{3}{ }^{35}$, and a toxicology and carcinogenesis study of NFT conducted by the National Toxicology Program ${ }^{36}$. In the present study, the 4- and 13-week administration groups were set for the objective of detection of early changes and subsequent changes in 8-OHdG levels and in vivo mutagenicity induced by $\mathrm{KBrO}_{3}$ or NFT, respectively. Body weights were measured every week. Animals were killed by exsanguination under isoflurane (Mylan Inc., Tokyo, Japan) anesthesia. At necropsy, the bilateral kidneys were collected, and their weights were measured. The kidneys-to-body weight ratios (relative weights) were calculated as grams organ weight/grams body weight. A portion of the kidney tissues was frozen with liquid nitrogen and stored at $-80^{\circ} \mathrm{C}$ for use in the in vivo mutation assay and 8-OHdG measurement. Another portion was homogenized in ISOGEN (Nippon Gene, Tokyo, Japan) and stored at $-80^{\circ} \mathrm{C}$ until used for isolation of total RNA.

\section{In vivo mutation assays}

6-Thioguanine (6-TG) and $\mathrm{Spi}^{-}$selections were performed using the methods described by Nohmi et al ${ }^{32}$. Briefly, genomic DNA was extracted from the kidneys of animals in each group using a RecoverEase DNA Isolation Kit (Agilent Technologies, Santa Clara, CA, USA), and lambda EG10 DNA (48 kb) was rescued as phages by in vitro packaging using Transpack Packaging Extract (Agilent Technologies). For 6-TG selection, packaged phages were incubated with Escherichia coli YG6020, which expresses Cre recombinase, and converted to plasmids carrying genes encoding glutamic-pyruvate transaminase and chloramphenicol acetyltransferase. Infected cells were mixed with molten soft agar and poured onto agar plates containing chloramphenicol and 6-TG. In order to determine the total number of rescued plasmids, infected cells were also poured on plates containing chloramphenicol without 6-TG. The plates were then incubated at $37^{\circ} \mathrm{C}$ for selection of 6-TGresistant colonies, and the gpt MF was calculated by dividing the number of gpt mutants after clonal correction by the number of rescued phages. Gpt mutations were characterized by amplifying a 739-bp DNA fragment containing the 456-bp coding region of the gpt gene ${ }^{32}$ and sequencing the PCR products with an Applied Biosystems 3730xl DNA Analyzer (Life Technologies, Carlsbad, CA, USA). For $\mathrm{Spi}^{-}$selection, packaged phages were incubated with $E$. coli XL-1 Blue MRA for survival titration and E. coli XL-1 
Blue MRA P2 for mutant selection. Infected cells were mixed with molten lambda-trypticase agar and poured onto lambda-trypticase agar plates. The next day, plaques $\left(\mathrm{Spi}^{-}\right.$ candidates) were punched out with sterilized glass pipettes, and the agar plugs were suspended in SM buffer. The Spi ${ }^{-}$ phenotype was confirmed by spotting the suspensions on three types of plates on which XL-1 Blue MRA, XL-1 Blue MRA P2, or WL95 P2 strain was spread with soft agar. Spi ${ }^{-}$ mutants, which manifested as clear plaques, were counted on every plate.

\section{Measurement of 8-OHdG}

Three animals in each group were selected randomly, and kidneys of those animals were used for the measurement of 8-OHdG. Renal DNA of $\mathrm{Nrf}^{2-/-} \mathrm{gpt}$ delta mice and $\mathrm{Nrf2^{+/+ }}$ gpt delta mice was extracted and digested as described previously ${ }^{37}$. Briefly, nuclear DNA was extracted with a DNA Extractor WB Kit (Wako Pure Chemical Industries). For further prevention of artifactual oxidation in the cell lysis step, deferoxamine mesylate (Sigma-Aldrich) was added to the lysis buffer. The DNA was digested to deoxynucleotides by treatment with nuclease P1 and alkaline phosphatase, using an 8-OHdG Assay Preparation Reagent Set (Wako Pure Chemical Industries). The levels of $8-\mathrm{OHdG}\left(8-\mathrm{OHdG} / 10^{5}\right.$ $\mathrm{dG}$ ) were measured by high-performance liquid chromatography with an electrochemical detection system (Coulochem II, ESA, Bedford, MA, USA) as previously reported ${ }^{19}$.

\section{$R N A$ isolation and quantitative real-time PCR for evaluation of $m R N A$ expression}

Total RNA was extracted using ISOGEN according to the manufacturer's instructions. cDNA of total RNA was obtained using a High-Capacity cDNA Reverse Transcription Kit (Life Technologies).

All PCR reactions were performed with an Applied Biosystems 7900HT FAST Real-Time PCR System with primers for mouse Nqol (coding NAD(P)H:quinone oxidoreductase 1) obtained from TaqMan ${ }^{\circledR}$ Gene Expression As- says and TaqMan ${ }^{\circledR}$ Rodent GAPDH Control Reagents. The expression levels of the target gene were calculated by the relative standard curve method and were determined as ratios to Gapdh levels. Data are presented as fold-change values of treated samples relative to controls.

\section{Statistical analysis}

The significance of differences in the results for body weights, kidney weights, mRNA expression levels, 8-OHdG levels, gpt and $\mathrm{Spi}^{-} \mathrm{MFs}$, and $g p t$ - and $\mathrm{Spi}^{-}-$mutation spectra were analyzed by Student's $t$-test depending on the homogeneity. $P$ values $<0.05$ were considered significant.

\section{Results}

\section{Body and kidney weights}

Body and kidney weights of Nrf2-proficient and Nrf2deficient mice treated with $\mathrm{KBrO}_{3}$ or NFT for 4 or 13 weeks are summarized in Fig. 1 and Table 1. For both genotypes and time points, no significant change was observed in body and kidney weights of treated and respective control animals.

\section{Quantitative real-time PCR for evaluation of Nqo1 $m R N A$ expression}

Expression levels of $\mathrm{NqOl}$ in the kidneys are shown in Fig. 2. In $\mathrm{Nrf}^{+/++}$mice, the expression level of $\mathrm{NqOl}$ was significantly increased by 4 or 13 weeks of exposure to $\mathrm{KBrO}_{3}$ $(P<0.01)$ and 13 weeks of exposure to NFT $(P<0.05)$. Four weeks of exposure to NFT resulted in a tendency toward increased expression of $\mathrm{NqO}$ in $\mathrm{Nrf2} 2^{+/+}$mice. In $\mathrm{Nrf} 2^{-/-}$mice, increased $\mathrm{Nqol}$ expression was not induced by $\mathrm{KBrO}_{3}$ or NFT treatment at either time point. The Nqol expression levels of control, $\mathrm{KBrO}_{3}$-treated, and NFT-treated $\mathrm{Nrf}^{-1-}$ mice were significantly lower $(P<0.01)$ than those of the corresponding $\mathrm{Nrf} 2^{+/+}$mice at both time points.
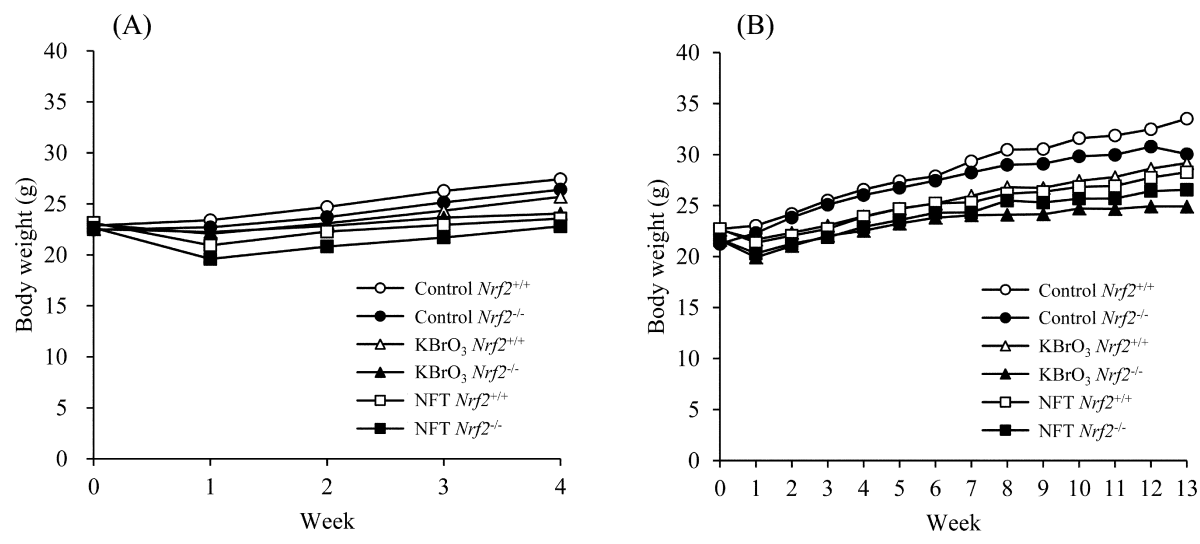

Fig. 1. Growth curves for $\mathrm{Nrf}^{+/ /+}$or $\mathrm{Nrf}^{-/-}$mice treated with $\mathrm{KBrO}_{3}$ or $\mathrm{NFT}$ for 4 weeks (A) or 13 weeks (B). For both genotypes, there were no significant differences in body weight between treated and untreated mice at either time point. 


\section{Measurement of 8-OHdG in kidney DNA}

The results of 8-OHdG measurement in the kidneys are shown in Fig. 3. At both time points, $\mathrm{KBrO}_{3}$ treatment significantly increased the level of 8-OHdG in the kidneys of both genotypes, and the degrees of 8 -OHdG increase were as follows: 4 weeks $\mathrm{Nrf}^{+++}, \times 2.8$; 4 weeks $\mathrm{Nrf2}^{-{ }^{--}}$,

Table 1. Final Body and Kidney Weights of Male $\mathrm{Nrf2}^{+/+}$or $\mathrm{Nrf} 2^{-/-}$gpt Delta Mice Treated with $\mathrm{KBrO}_{3}$ or $\mathrm{NFT}_{\text {for }} 4$ or 13 Weeks

\begin{tabular}{|c|c|c|c|c|c|c|c|}
\hline & & \multicolumn{3}{|c|}{$\mathrm{Nrf2}^{+/+}$} & \multicolumn{3}{|c|}{$N r f 2^{-/-}$} \\
\hline & & Control & $\begin{array}{c}1,500 \mathrm{ppm} \\
\mathrm{KBrO}_{3}\end{array}$ & $\begin{array}{c}2,500 \mathrm{ppm} \\
\text { NFT }\end{array}$ & Control & $\begin{array}{c}1,500 \mathrm{ppm} \\
\mathrm{KBrO}_{3}\end{array}$ & $\begin{array}{c}2,500 \mathrm{ppm} \\
\mathrm{NFT}\end{array}$ \\
\hline \multirow[t]{4}{*}{4 weeks } & No. of animals & 4 & 5 & 5 & 4 & 4 & 5 \\
\hline & Final body weights (g) & $27.43 \pm 2.59 b$ & $25.70 \pm 2.35$ & $23.56 \pm 2.15$ & $26.40 \pm 2.18$ & $24.05 \pm 1.26$ & $22.80 \pm 1.46$ \\
\hline & Kidneys (g) & $0.33 \pm 0.03$ & $0.32 \pm 0.04$ & $0.33 \pm 0.04$ & $0.32 \pm 0.03$ & $0.32 \pm 0.04$ & $0.32 \pm 0.04$ \\
\hline & Kidneys $(\mathrm{g} \%)^{\mathrm{a}}$ & $1.22 \pm 0.11$ & $1.26 \pm 0.09$ & $1.38 \pm 0.06$ & $1.20 \pm 0.10$ & $1.32 \pm 0.16$ & $1.38 \pm 0.13$ \\
\hline \multirow[t]{4}{*}{13 weeks } & No. of animals & 8 & 8 & 8 & 6 & 8 & 8 \\
\hline & Final body weights (g) & $33.53 \pm 3.45$ & $29.18 \pm 2.45$ & $28.28 \pm 1.67$ & $30.05 \pm 2.38$ & $24.91 \pm 1.80$ & $26.55 \pm 1.39$ \\
\hline & Kidneys (g) & $0.35 \pm 0.03$ & $0.34 \pm 0.03$ & $0.38 \pm 0.05$ & $0.35 \pm 0.05$ & $0.34 \pm 0.06$ & $0.33 \pm 0.04$ \\
\hline & Kidneys $(\mathrm{g} \%)^{\mathrm{a}}$ & $1.06 \pm 0.08$ & $1.16 \pm 0.08$ & $1.35 \pm 0.12$ & $1.18 \pm 0.15$ & $1.38 \pm 0.30$ & $1.24 \pm 0.14$ \\
\hline
\end{tabular}

aKidneys-to-body weight ratios (relative weights) are given as grams organ weight/grams body weight. ${ }^{\mathrm{b}} \mathrm{Mean} \pm \mathrm{SD}$.

(A)

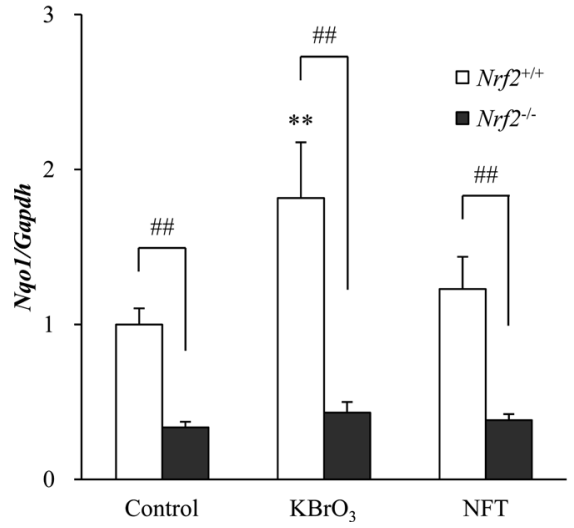

(B)

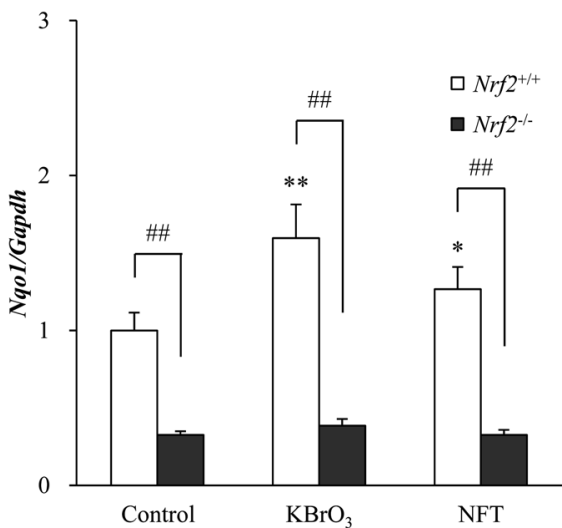

Fig. 2. Changes in mRNA levels of the Nrf2-target gene $\mathrm{Nqol}$ in the kidneys of $\mathrm{Nrf}^{+/+}$or $\mathrm{Nrf}^{-/-}$mice treated with $\mathrm{KBrO}_{3}$ or $\mathrm{NFT}_{\text {for }} 4$ weeks (A) or 13 weeks (B). Values are means $\pm \mathrm{SD}$. *Significantly different $(P<0.05)$ from the respective control group. ${ }^{* *}$ Significantly different $(P<0.01)$ from the respective control group. \#\#Significantly different $(P<0.01)$ from the respective $\mathrm{Nrf} 2^{+/+}$animals.

(A)

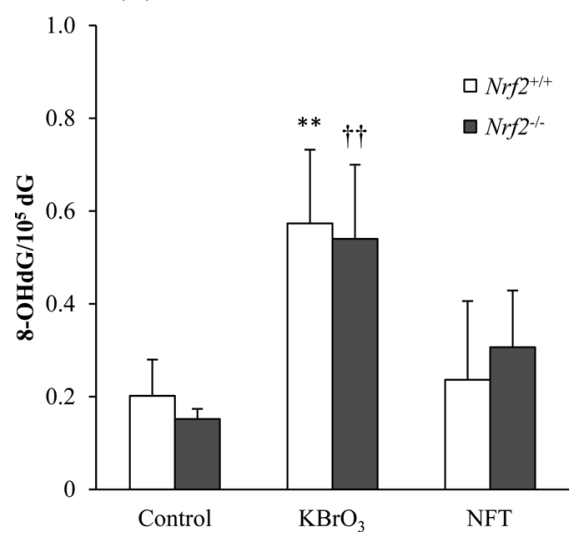

(B)

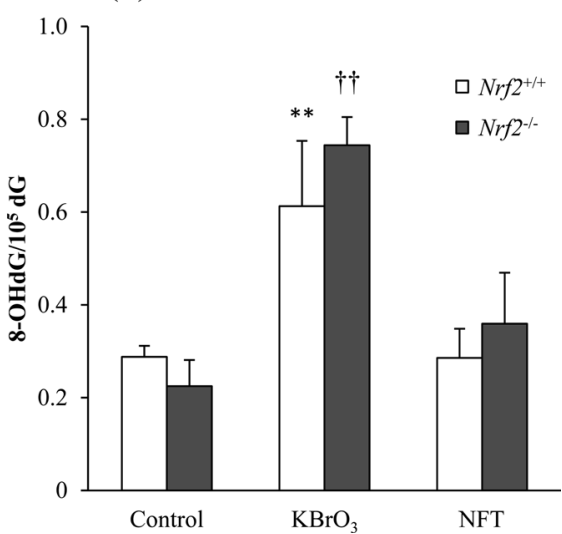

Fig. 3. 8-OHdG levels in the kidneys of $\mathrm{Nrf}^{+/ /+}$or $\mathrm{Nrf2^{-/- }}$ mice treated with $\mathrm{KBrO}_{3}$ or $\mathrm{NFT}$ for 4 weeks (A) or 13 weeks (B). Values are means $\pm \mathrm{SD}$. ${ }^{* *}$ Significantly different $(P<0.01)$ from the respective control group. $\dagger \dagger$ Significantly different $(P<0.01)$ from the respective control group. 
$\times 3.6 ; 13$ weeks $\mathrm{Nrf2}^{+/+}, \times 2.1 ; 13$ weeks $\mathrm{Nrf2}^{-/-}, \times 3.3$ (vs. respective control). On the other hand, NFT treatment did not increase the level of $8-\mathrm{OHdG}$ in the kidneys of either genotype at either time point. There was no significant difference in 8-OHdG level between the $\mathrm{Nrf2}$-proficient and $\mathrm{Nrf} 2$-deficient mice of each treatment group.

\section{In vivo mutation assay of kidneys}

The results of the gpt assay of the kidneys of Nrf2-proficient and $\mathrm{Nrf2}$-deficient mice treated with $\mathrm{KBrO}_{3}$ or NFT are shown in Tables 2 to 5 . At both time points, $\mathrm{KBrO}_{3}$ treated mice showed a significant increase or tendency toward increase in gpt MFs compared with those in the respective control groups (Table 2). The degrees of increase in $g p t$ MFs caused by 13 weeks of treatment with $\mathrm{KBrO}_{3}$ were as follows: $\mathrm{Nrf2^{+/+ }}, \times 2.2 ; \mathrm{Nrf}^{-/-}, \times 4.4$ (vs. respective control; Table 2). Specific MFs of deletion mutations were increased in the spectrum analysis of $g p t$ mutants in $\mathrm{KBrO}_{3}$ treated mice (Table 3 and 4). The frequencies of deletion mutations of more than two base pairs were increased by 13
Table 2. Gpt MFs in the Kidneys of $\mathrm{Nrf2}^{+/+}$or $\mathrm{Nrf2}^{-/-}$gpt Delta Mice Treated with $\mathrm{KBrO}_{3}$ or NFT for 4 or 13 Weeks

\begin{tabular}{|c|c|c|c|c|}
\hline $\begin{array}{l}\text { Treatment } \\
\text { period }\end{array}$ & Genotype & Treatment & $\begin{array}{c}\text { No. of } \\
\text { animals }\end{array}$ & $\mathrm{MF}^{\#}$ \\
\hline \multirow[t]{6}{*}{4 weeks } & $N r f 2^{+/+}$ & Control & 4 & $0.36 \pm 0.09$ \\
\hline & & 1,500 ppm $\mathrm{KBrO}_{3}$ & 5 & $0.70 \pm 0.19^{*}$ \\
\hline & & $2,500 \mathrm{ppm}$ NFT & 5 & $0.55 \pm 0.27$ \\
\hline & $N r f 2^{-/-}$ & Control & 4 & $0.33 \pm 0.08$ \\
\hline & & 1,500 ppm $\mathrm{KBrO}_{3}$ & 4 & $0.59 \pm 0.15$ \\
\hline & & 2,500 ppm NFT & 5 & $0.55 \pm 0.06$ \\
\hline \multirow[t]{8}{*}{13 weeks } & $N r f 2^{+/+}$ & Control & 8 & $0.69 \pm 0.43$ \\
\hline & & 1,500 ppm $\mathrm{KBrO}_{3}$ & 8 & $1.57 \pm 0.67 * *$ \\
\hline & $N r f 2^{-/-}$ & Control & 5 & $0.48 \pm 0.18$ \\
\hline & & 1,500 ppm $\mathrm{KBrO}_{3}$ & 8 & $1.86 \pm 0.78 \dagger \dagger$ \\
\hline & $N r f 2^{+/+}$ & Control & 8 & $0.38 \pm 0.17$ \\
\hline & & 2,500 ppm NFT & 7 & $1.04 \pm 0.24 * *$ \\
\hline & $N r f 2^{-/-}$ & Control & 5 & $0.39 \pm 0.13$ \\
\hline & & $2,500 \mathrm{ppm}$ NFT & 8 & $1.40 \pm 0.30 \dagger \dagger$ \\
\hline
\end{tabular}

$* P<0.05$ vs. respective control group; $* * P<0.01$ vs. respective control group. $\dagger \uparrow P<0.01$ vs. respective control group; MF, Mutant frequency; \#Mean \pm SD. Gpt assays were performed in three divided groups: the 4-week treatment group, 13 -week treatment of $\mathrm{KBrO} 3$ group, and the 13-week treatment of NFT group.

Table 3. Mmutation Spectra of gpt Mutant Colonies in the Kidneys of $\mathrm{Nrf}^{+/+}$Or $\mathrm{Nrf2^{-/- }}$ gpt Delta Mice Treated with $\mathrm{KBrO}_{3}$ or NFT for 4 Weeks

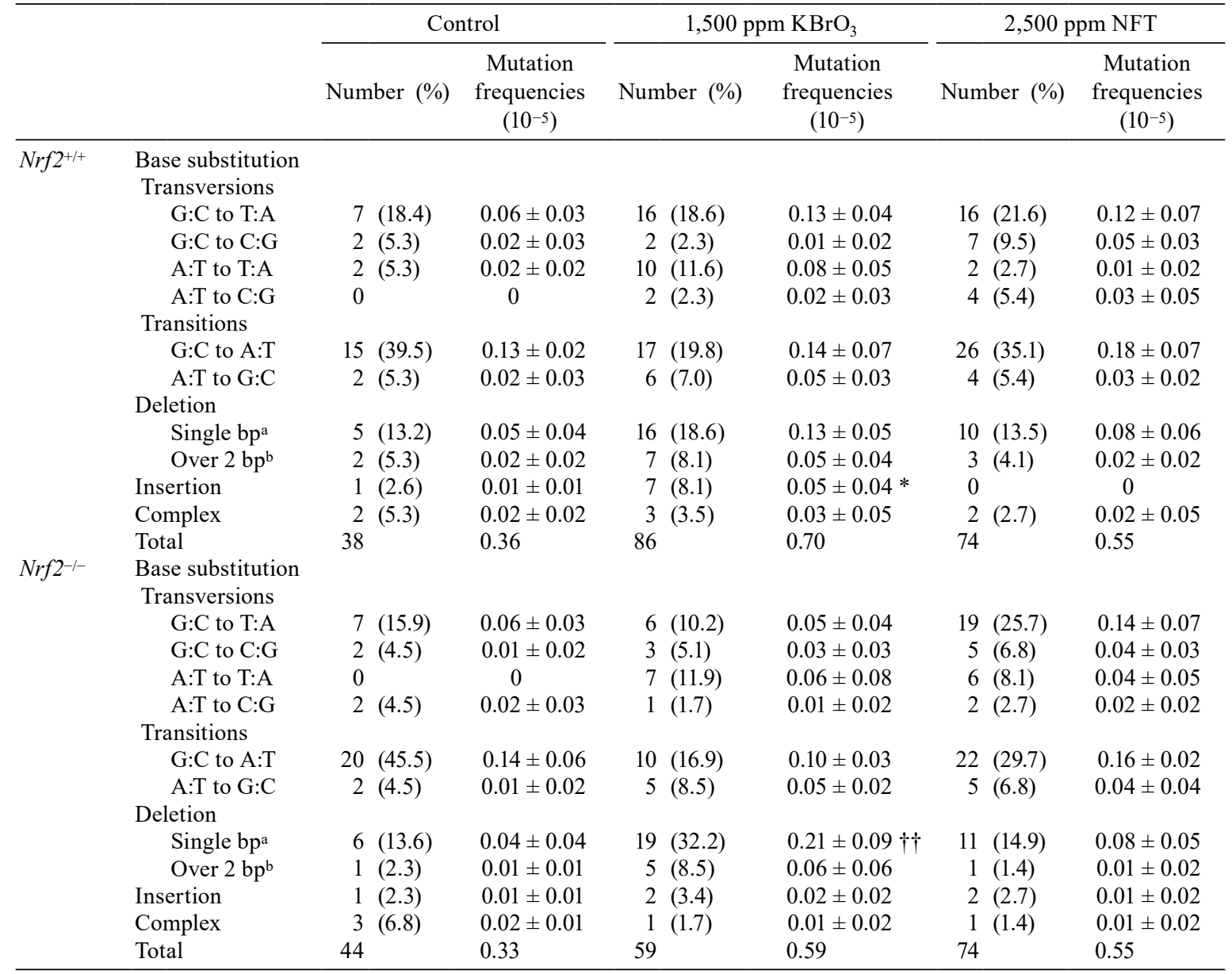

${ }_{* P<0.05}$ vs. respective control group; $\dagger \dagger P<0.01$ vs. respective control group. aSingle base pair deletion mutation; beletion mutation of more than two base pairs. 
weeks of treatment with $\mathrm{KBrO}_{3}$ in both genotypes (Table 4). Furthermore, in both genotypes, gpt MFs were increased by 13 weeks of treatment with NFT, despite no change at 4 weeks (Table 2). The degrees of increase in gpt MFs caused by 13 weeks of treatment with NFT were as follows: $N r f 2^{+/+}$, $\times 2.1 ; \mathrm{Nrf}^{-1-}, \times 3.3$ (vs. respective control; Table 2). In both genotypes, guanine base substitution mutations, including $\mathrm{G}: \mathrm{C}$ to $\mathrm{T}: \mathrm{A}$ or $\mathrm{G}: \mathrm{C}$ to $\mathrm{C}: \mathrm{G}$ transversion mutations, were increased by 13 weeks of treatment with NFT (Table 5).
The results of the $\mathrm{Spi}^{-}$assay of the kidneys of $\mathrm{Nrf2}$-proficient and $\mathrm{Nrf2}$-deficient mice treated with $\mathrm{KBrO}_{3}$ or NFT are shown in Tables 6 to 8 . At both time points, $\mathrm{KBrO}_{3}$ treated mice showed a significant increase or tendency toward increase in $\mathrm{Spi}^{-}$MFs compared with those in the respective control groups (Table 6). The degrees of increase in $\mathrm{Spi}^{-}$MFs caused by 13 weeks of treatment with $\mathrm{KBrO}_{3}$ were as follows: $N r f 2^{+/+}, \times 3.0 ; \mathrm{Nrf} 2^{-1-}, \times 4.1$ (vs. respective control; Table 6). In the spectrum analysis of $\mathrm{Spi}^{-}$mutants

Table 4. Mutation Spectra of gpt Mutant Colonies in the Kidneys of $\mathrm{Nrf2^{+/+ }}$ or $\mathrm{Nrf} 2^{-/-}$gpt Delta Mice Treated with $\mathrm{KBrO}_{3}$ for 13 Weeks

\begin{tabular}{|c|c|c|c|c|c|c|c|c|}
\hline & \multicolumn{4}{|c|}{$N r f 2^{+/+}$} & \multicolumn{4}{|c|}{$\mathrm{Nrf2^{-/- }}$} \\
\hline & \multicolumn{2}{|c|}{ Control } & \multicolumn{2}{|c|}{1,500 ppm $\mathrm{KBrO}_{3}$} & \multicolumn{2}{|c|}{ Control } & \multicolumn{2}{|c|}{$1,500 \mathrm{ppm} \mathrm{KBrO}_{3}$} \\
\hline & Number (\%) & $\begin{array}{l}\text { Mutation } \\
\text { frequencies } \\
\quad\left(10^{-5}\right)\end{array}$ & Number (\%) & $\begin{array}{l}\text { Mutation } \\
\text { frequencies } \\
\quad\left(10^{-5}\right)\end{array}$ & Number (\%) & $\begin{array}{l}\text { Mutation } \\
\text { frequencies } \\
\left(10^{-5}\right)\end{array}$ & Number (\%) & $\begin{array}{c}\text { Mutation } \\
\text { frequencies } \\
\left(10^{-5}\right)\end{array}$ \\
\hline \multicolumn{9}{|c|}{ Base substitution } \\
\hline \multicolumn{9}{|c|}{ Transversions } \\
\hline $\mathrm{G}: \mathrm{C}$ to $\mathrm{T}: \mathrm{A}$ & 15 (25.9) & $0.18 \pm 0.16$ & $20(10.7)$ & $0.16 \pm 0.11$ & 13 (28.9) & $0.13 \pm 0.06$ & $15(8.2)$ & $0.15 \pm 0.11$ \\
\hline $\mathrm{G}: \mathrm{C}$ to $\mathrm{C}: \mathrm{G}$ & $2(3.4)$ & $0.03 \pm 0.06$ & $5(2.7)$ & $0.04 \pm 0.05$ & $1(2.2)$ & $0.01 \pm 0.02$ & $2(1.1)$ & $0.02 \pm 0.03$ \\
\hline A:T to T:A & 0 & 0 & $11(5.9)$ & $0.10 \pm 0.11^{*}$ & $3(6.7)$ & $0.03 \pm 0.03$ & $28(15.4)$ & $0.27 \pm 0.16 \dagger$ \\
\hline $\mathrm{A}: \mathrm{T}$ to $\mathrm{C}: \mathrm{G}$ & 0 & 0 & $10(5.3)$ & $0.07 \pm 0.06^{* *}$ & 0 & 0 & $1(0.5)$ & $0.01 \pm 0.03$ \\
\hline \multicolumn{9}{|l|}{ Transitions } \\
\hline $\mathrm{G}: \mathrm{C}$ to $\mathrm{A}: \mathrm{T}$ & $19(32.8)$ & $0.22 \pm 0.21$ & 33 (17.6) & $0.27 \pm 0.13$ & $19(42.2)$ & $0.20 \pm 0.08$ & $27(14.8)$ & $0.29 \pm 0.16$ \\
\hline A:T to $\mathrm{G}: \mathrm{C}$ & $4(6.9)$ & $0.05 \pm 0.08$ & $7(3.7)$ & $0.06 \pm 0.09$ & $3(6.7)$ & $0.04 \pm 0.03$ & $4(2.2)$ & $0.05 \pm 0.06$ \\
\hline \multicolumn{9}{|l|}{ Deletion } \\
\hline Single $b p^{a}$ & $11(19.0)$ & $0.12 \pm 0.11$ & $69(36.9)$ & $0.60 \pm 0.34^{* *}$ & $3(6.7)$ & $0.03 \pm 0.03$ & $62(34.1)$ & $0.65 \pm 0.41 \dagger \dagger$ \\
\hline Over 2 bp $^{b}$ & $2(3.4)$ & $0.03 \pm 0.05$ & $20(10.7)$ & $0.17 \pm 0.07 * *$ & $1(2.2)$ & $0.01 \pm 0.03$ & $29(15.9)$ & $0.30 \pm 0.13 \dagger \dagger$ \\
\hline Insertion & $4(6.9)$ & $0.04 \pm 0.07$ & $8(4.3)$ & $0.07 \pm 0.07$ & $1(2.2)$ & $0.01 \pm 0.02$ & $6(3.3)$ & $0.06 \pm 0.10$ \\
\hline Complex & $1(1.7)$ & $0.01 \pm 0.02$ & $4(2.1)$ & $0.03 \pm 0.04$ & $1(2.2)$ & $0.01 \pm 0.03$ & $8(4.4)$ & $0.07 \pm 0.05 \dagger$ \\
\hline Total & 58 & 0.69 & 187 & 1.57 & 45 & 0.48 & 182 & 1.86 \\
\hline
\end{tabular}

$* P<0.05$ vs. respective control group; $* * P<0.01$ vs. respective control group; $\uparrow P<0.05$ vs. respective control group; $\dagger \uparrow P 0.01$ vs. respective control group. aSingle base pair deletion mutation; bDeletion mutation of more than two base pairs.

Table 5. Mutation Spectra of gpt Mutant Colonies in the Kidneys of $N r f 2^{+/+}$or $N r f 2^{-/-}$gpt Delta Mice Treated with NFT for 13 Weeks

\begin{tabular}{|c|c|c|c|c|c|c|c|c|}
\hline & \multicolumn{4}{|c|}{$N r f 2^{+/+}$} & \multicolumn{4}{|c|}{$N r f 2^{-/-}$} \\
\hline & \multicolumn{2}{|c|}{ Control } & \multicolumn{2}{|c|}{$2,500 \mathrm{ppm}$ NFT } & \multicolumn{2}{|c|}{ Control } & \multicolumn{2}{|c|}{ 2,500 ppm NFT } \\
\hline & $\begin{array}{c}\text { Number } \\
(\%)\end{array}$ & $\begin{array}{l}\text { Mutation } \\
\text { frequencies } \\
\qquad\left(10^{-5}\right)\end{array}$ & $\begin{array}{c}\text { Number } \\
(\%)\end{array}$ & $\begin{array}{c}\text { Mutation } \\
\text { frequencies } \\
\quad\left(10^{-5}\right)\end{array}$ & $\begin{array}{c}\text { Number } \\
(\%)\end{array}$ & $\begin{array}{c}\text { Mutation } \\
\text { frequencies } \\
\quad\left(10^{-5}\right)\end{array}$ & $\begin{array}{c}\text { Number } \\
(\%)\end{array}$ & $\begin{array}{l}\text { Mutation } \\
\text { frequencies } \\
\qquad\left(10^{-5}\right)\end{array}$ \\
\hline \multicolumn{9}{|c|}{ Base substitution } \\
\hline \multicolumn{9}{|l|}{ Transversions } \\
\hline $\mathrm{G}: \mathrm{C}$ to $\mathrm{T}: \mathrm{A}$ & $9(22.0)$ & $0.08 \pm 0.07$ & $31(28.2)$ & $0.29 \pm 0.05^{* *}$ & $8(20.5)$ & $0.07 \pm 0.05$ & $47 \quad(30.9)$ & $0.43 \pm 0.15 \dagger \dagger$ \\
\hline $\mathrm{G}: \mathrm{C}$ to $\mathrm{C}: \mathrm{G}$ & $4(9.8)$ & $0.04 \pm 0.05$ & $28(25.5)$ & $0.26 \pm 0.06^{* *}$ & $3(7.7)$ & $0.02 \pm 0.03$ & $38(25.0)$ & $0.37 \pm 0.17 \dagger \dagger$ \\
\hline A:T to T:A & 0 & 0 & $5(4.5)$ & $0.05 \pm 0.07$ & $1(2.6)$ & $0.01 \pm 0.02$ & $7(4.6)$ & $0.07 \pm 0.06 \dagger$ \\
\hline$A: T$ to $C: G$ & $1(2.4)$ & $0.01 \pm 0.02$ & $2(1.8)$ & $0.02 \pm 0.04$ & 0 & 0 & $3(2.0)$ & $0.02 \pm 0.03$ \\
\hline \multicolumn{9}{|l|}{ Transitions } \\
\hline $\mathrm{G}: \mathrm{C}$ to $\mathrm{A}: \mathrm{T}$ & $19(46.3)$ & $0.18 \pm 0.10$ & $26(23.6)$ & $0.24 \pm 0.12$ & $16(41.0)$ & $0.17 \pm 0.07$ & $27(17.8)$ & $0.25 \pm 0.09$ \\
\hline A:T to $\mathrm{G}: \mathrm{C}$ & $1(2.4)$ & $0.01 \pm 0.02$ & $4(3.6)$ & $0.04 \pm 0.04$ & 0 & 0 & $3(2.0)$ & $0.03 \pm 0.04$ \\
\hline \multicolumn{9}{|l|}{ Deletion } \\
\hline Single bp ${ }^{a}$ & $4(9.8)$ & $0.04 \pm 0.04$ & $7(6.4)$ & $0.06 \pm 0.05$ & $9(23.1)$ & $0.09 \pm 0.09$ & $10(6.6)$ & $0.09 \pm 0.05$ \\
\hline Over $2 b^{b}$ & 2 (4.9) & $0.03 \pm 0.05$ & $2(1.8)$ & $0.02 \pm 0.03$ & $1(2.6)$ & $0.02 \pm 0.03$ & $3(2.0)$ & $0.03 \pm 0.04$ \\
\hline Insertion & 0 & 0 & $1(0.9)$ & $0.01 \pm 0.02$ & $1(2.6)$ & $0.01 \pm 0.02$ & $5(3.3)$ & $0.04 \pm 0.06$ \\
\hline Complex & $1(2.4)$ & $0.01 \pm 0.03$ & $4(3.6)$ & $0.04 \pm 0.07$ & 0 & 0 & $9(5.9)$ & $0.08 \pm 0.10$ \\
\hline Total & 41 & 0.38 & 110 & 1.04 & 39 & 0.39 & 152 & 1.40 \\
\hline
\end{tabular}

$* * P<0.01$ vs. respective control group; $\uparrow P<0.05$ vs. respective control group; $\uparrow \uparrow P<0.01$ vs. respective control group. aSingle base pair deletion mutation; bDeletion mutation of more than two base pairs. 
in $\mathrm{KBrO}_{3}$-treated mice, specific MFs of deletion mutations were increased (Table 7 and 8), consistent with the spectrum analysis of $g p t$ mutants. In both genotypes and at both time points, NFT treatment did not change $\mathrm{Spi}^{-}$MFs (Table 6).

\section{Discussion}

It is well known that transcriptional upregulation of various antioxidant enzymes, including NQO1 and HO1, is regulated by NRF2, which protect cells from oxidative

Table 6. $\mathrm{Spi}^{-} \mathrm{MFs}$ in the Kidneys of $\mathrm{Nrf2}^{+/+}$or $\mathrm{Nrf2^{-/- }}$ gpt Delta Mice Treated with $\mathrm{KBrO}_{3}$ or NFT for 4 or 13 Weeks

\begin{tabular}{|c|c|c|c|c|}
\hline $\begin{array}{l}\text { Treatment } \\
\text { period }\end{array}$ & Genotype & Treatment & $\begin{array}{c}\text { No. of } \\
\text { animals }\end{array}$ & $\mathrm{MF}^{\#}$ \\
\hline \multirow[t]{6}{*}{4 weeks } & $N r f 2^{+/+}$ & Control & 4 & $0.24 \pm 0.13$ \\
\hline & & 1,500 ppm $\mathrm{KBrO}_{3}$ & 5 & $0.43 \pm 0.16$ \\
\hline & & $2,500 \mathrm{ppm}$ NFT & 5 & $0.30 \pm 0.13$ \\
\hline & $N r f 2^{-/-}$ & Control & 4 & $0.18 \pm 0.05$ \\
\hline & & 1,500 ppm $\mathrm{KBrO}_{3}$ & 4 & $0.36 \pm 0.10$ \\
\hline & & 2,500 ppm NFT & 5 & $0.26 \pm 0.07$ \\
\hline \multirow[t]{6}{*}{13 weeks } & $N r f 2^{+/+}$ & Control & 8 & $0.31 \pm 0.06$ \\
\hline & & 1,500 ppm $\mathrm{KBrO}_{3}$ & 8 & $0.85 \pm 0.16^{* *}$ \\
\hline & & $2,500 \mathrm{ppm}$ NFT & 7 & $0.33 \pm 0.07$ \\
\hline & $N r f 2^{-1-}$ & Control & 5 & $0.28 \pm 0.06$ \\
\hline & & 1,500 ppm $\mathrm{KBrO}_{3}$ & 8 & $0.92 \pm 0.28 \dagger \dagger$ \\
\hline & & $2,500 \mathrm{ppm}$ NFT & 8 & $0.36 \pm 0.14$ \\
\hline
\end{tabular}

$* P<0.05$ vs. respective control group; $* * P<0.01$ vs. respective control group. $\uparrow \uparrow P<0.01$ vs. respective control group; MF, Mutant frequency; \#Means $\pm \mathrm{SD}$. Spi- assays were performed in two divided groups: the 4-week treatment group and 13-week treatment group.

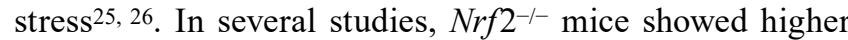
sensitivity to various toxicants that induced oxidative stress $^{27-31}$. In fact, the mRNA expression level of Nqol in the kidneys of vehicle-treated $\mathrm{Nrf2^{-/- }}$ mice was significantly lower than that of vehicle-treated $\mathrm{Nrf}^{+/+}$mice, and there was no elevation of the level in $\mathrm{KBrO}_{3}$ - or NFT-treated $\mathrm{Nrf2^{-/- }}$ mice despite the elevation in $\mathrm{Nrf2^{+/+ }}$ mice. Thus, in the present study, $N r f 2^{-/-}$mice were confirmed to be susceptible to oxidative stress. As previously reported, using this highly oxidative stress-sensitive animal gives us important knowledge about the involvement of oxidative stress in chemical-induced genotoxicity and carcinogenesis ${ }^{27-31}$.

Four or thirteen weeks of administration of $1,500 \mathrm{ppm}$ $\mathrm{KBrO}_{3}$ in drinking water significantly increased the level of $8-\mathrm{OHdG}$ in the kidneys of both genotypes. At both time points, the degree of 8-OHdG increase was higher in $\mathrm{Nrf2-1-}$ mice than in $\mathrm{Nrf2^{+/+ }}$ mice. Meanwhile, increases in $g p t$ and $\mathrm{Spi}^{-}$MFs were detected, and the tendencies of the degrees of increase in gpt and $\mathrm{Spi}^{-} \mathrm{MFs}$ at 13 weeks of exposure were the same as those of $8-\mathrm{OHdG}$. In the spectrum analysis of gpt and $\mathrm{Spi}^{-}$mutants in $\mathrm{KBrO}_{3}$-treated $\mathrm{Nrf}^{-/-}$mice, specific MFs of deletion mutations were increased, consistent with a previous study of rats $^{24}$, and they were accompanied by an increase in the frequencies of deletion mutations of more than two base pairs. An in vitro report demonstrated that error in the repair process of $8-\mathrm{OHdG}$ induced by $\mathrm{KBrO}_{3}$ treatment caused double-strand breaks (DSBs) in human cells and that DSBs resulted in a large deletion ${ }^{38}$. Considering these mechanisms, the increase in size of deletion mutations might reflect the accumulation of high amounts

Table 7. Mutation Spectra of Spi- Plaques in the Kidneys of $\mathrm{Nrf}^{+/+}$or $\mathrm{Nrf} 2^{-/-}$gpt Delta Mice Treated with $\mathrm{KBrO}_{3}$ or $\mathrm{NFT}$ for 4 Weeks

\begin{tabular}{|c|c|c|c|c|c|c|c|}
\hline & & \multicolumn{2}{|c|}{ Control } & \multicolumn{2}{|c|}{1,500 ppm $\mathrm{KBrO}_{3}$} & \multicolumn{2}{|c|}{ 2,500 ppm NFT } \\
\hline & & Number $(\%)$ & $\begin{array}{c}\text { Mutation } \\
\text { frequencies } \\
\qquad\left(10^{-5}\right)\end{array}$ & Number $(\%)$ & $\begin{array}{l}\text { Mutation } \\
\text { frequencies } \\
\qquad\left(10^{-5}\right)\end{array}$ & Number $(\%)$ & $\begin{array}{c}\text { Mutation } \\
\text { frequencies } \\
\left(10^{-5}\right)\end{array}$ \\
\hline \multirow[t]{11}{*}{$N r f 2^{+/+}$} & \multicolumn{7}{|l|}{ Single bp deletion } \\
\hline & \multirow[t]{2}{*}{ Simple } & $6(25.0)$ & $0.06 \pm 0.04$ & $6(9.2)$ & $0.04 \pm 0.05$ & $6(12.0)$ & $0.03 \pm 0.03$ \\
\hline & & 0 & 0 & $5(7.7)$ & $0.03 \pm 0.04$ & $1(2.0)$ & $0.01 \pm 0.01$ \\
\hline & \multirow[t]{2}{*}{ In run } & 4 (16.7) & $0.04 \pm 0.03$ & $17(26.2)$ & $0.12 \pm 0.08$ & $15(30.0)$ & $0.09 \pm 0.09$ \\
\hline & & $5(20.8)$ & $0.05 \pm 0.03$ & $18(27.7)$ & $0.11 \pm 0.09$ & $13(26.0)$ & $0.08 \pm 0.04$ \\
\hline & 2 to $1 \mathrm{~kb}$ deletion ${ }^{\mathrm{a}}$ & 0 & 0 & $5(7.7)$ & $0.03 \pm 0.04$ & 0 & 0 \\
\hline & Over $1 \mathrm{~kb}$ deletion $\mathrm{b}$ & $8(33.3)$ & $0.08 \pm 0.10$ & $12(18.5)$ & $0.08 \pm 0.11$ & $12(24.0)$ & $0.07 \pm 0.07$ \\
\hline & Complex & $1(4.2)$ & $0.01 \pm 0.02$ & $2(3.1)$ & $0.01 \pm 0.03$ & $1(2.0)$ & $0.01 \pm 0.01$ \\
\hline & Insertion & 0 & 0 & 0 & 0 & $1(2.0)$ & $0.01 \pm 0.02$ \\
\hline & Base substitution & 0 & 0 & 0 & 0 & $1(2.0)$ & $0.00 \pm 0.01$ \\
\hline & Total & 24 & 0.24 & 65 & 0.43 & 50 & 0.30 \\
\hline \multirow[t]{11}{*}{$\operatorname{Nrf2^{-1-}}$} & \multicolumn{7}{|l|}{ Single bp deletion } \\
\hline & \multirow[t]{2}{*}{ Simple } & 0 & 0 & $7(20.6)$ & $0.08 \pm 0.05$ & $3(7.9)$ & $0.02 \pm 0.02$ \\
\hline & & $2(8.0)$ & $0.01 \pm 0.02$ & $2(5.9)$ & $0.02 \pm 0.02$ & 0 & 0 \\
\hline & \multirow[t]{2}{*}{ In run } & $7(28.0)$ & $0.04 \pm 0.03$ & $9(26.5)$ & $0.10 \pm 0.09$ & $12(31.6)$ & $0.08 \pm 0.05$ \\
\hline & & $8(32.0)$ & $0.06 \pm 0.08$ & $8(23.5)$ & $0.09 \pm 0.06$ & $11(28.9)$ & $0.08 \pm 0.05$ \\
\hline & 2 to $1 \mathrm{~kb}$ deletion ${ }^{\mathrm{a}}$ & 0 & 0 & $3(8.8)$ & $0.03 \pm 0.04$ & 0 & 0 \\
\hline & Over $1 \mathrm{~kb}$ deletion ${ }^{\mathrm{b}}$ & $8(32.0)$ & $0.07 \pm 0.06$ & $4(11.8)$ & $0.04 \pm 0.04$ & 12 (31.6) & $0.08 \pm 0.05$ \\
\hline & Complex & 0 & 0 & $1(2.9)$ & $0.01 \pm 0.01$ & 0 & 0 \\
\hline & Insertion & 0 & 0 & 0 & 0 & 0 & 0 \\
\hline & Base substitution & 0 & 0 & 0 & 0 & 0 & 0 \\
\hline & Total & 25 & 0.18 & 34 & 0.36 & 38 & 0.26 \\
\hline
\end{tabular}

aDeletion mutation of two or more but less than one thousand base pairs. bDeletion mutation of more than one thousand base pairs. 
of 8-OHdG in the nuclei due to $\mathrm{KBrO}_{3}$. These results suggested that the formation of $8-\mathrm{OHdG}$ induced by oxidative stress was directly involved in the increase of deletion mutations in $\mathrm{KBrO}_{3}$-treated animals. It was suspected that the formation of high amounts of 8-OHdG owing to the strong potential of $\mathrm{KBrO}_{3}$ as an oxidizing agent might exceed the repairing capacity of base excision repair enzymes.

Four or thirteen weeks of administration of $2,500 \mathrm{ppm}$ NFT in diet did not increase the level of 8-OHdG in the kidneys of either genotype. In our previous study, the level of 8-OHdG was increased in the kidneys of $\mathrm{Nrf2}^{-/-}$mice by oral administration of NFT at $70 \mathrm{mg} / \mathrm{kg}^{39}$. The lower exposure levels of NFT in the present study compared with those in our previous study might be a cause of the static level of 8-OHdG. On the other hand, 13 weeks administration of $2,500 \mathrm{ppm}$ NFT in diet significantly increased gpt MFs with guanine base substitution mutations in the kidneys of both genotypes. The degree of increase in gpt MFs was higher in $\mathrm{Nrf}^{-/-}$mice than in $\mathrm{Nrf2^{+/+ }}$ mice. These results implied that the vulnerability to oxidative stress caused by the deficiency of $N r f 2$ leads to more mutations in NFT-treated mice. Thus, in the genotoxic mechanism of NFT, the formation of 8 -OHdG induced by oxidative stress might not be involved in the increase of guanine base substitution mutations. Considering our previous studies, which suggested the involvement of oxidative stress in the chemical structure-related genotoxic mechanism of NFT in rodents ${ }^{24,38}$, factors other than 8-OHdG might be crucial to the genotoxicity of NFT, though the present study did not identify them.

In recent years, the level of 8-OHdG has been frequently used as a marker of oxidative stress in human diseases ${ }^{40,41}$. In addition, some reports demonstrated the involvement of oxidative stress in chemical-induced genotoxicity and carcinogenesis using the increase in $8-\mathrm{OHdG}$ level as a parameter of oxidative stress in experimental animals $27-31$. However, the relationship between the formation of $8-\mathrm{OHdG}$ and subsequent mutations, including deletion mutations and $\mathrm{G}: \mathrm{C}$ to T:A transversions, had not been clarified. The revelation of the relationship between 8-OHdG and several types of mutations induced by $\mathrm{KBrO}_{3}$ or NFT provides new insight into oxidative stress-related in vivo mutagenicity.

The present study demonstrated that the formation of 8-OHdG, which resulted from the oxidizing potential of $\mathrm{KBrO}_{3}$, was directly involved in the increase of deletion mutations; however, oxidative stress-related factors other than 8-OHdG might play a critical role in NFT-induced guanine base substitution mutations. This was the first study to investigate the relationship between $8-\mathrm{OHdG}$ and several types of mutations caused by oxidative stress-inducing chemicals. Accumulation of detailed examinations like this, such as further research on 8-OHdG with respect to individual chemical substances, will lead to accurate risk assessment of oxidative stress in carcinogenicity.

Disclosure of Potential Conflicts of Interest: The authors declare that they have no competing interests.

Table 8. Mutation Spectra of Spi- Plaques in the Kidneys of $\mathrm{Nrf}^{+/+}$or $\mathrm{Nrf2^{-/- }}$ gpt Delta Mice Treated with $\mathrm{KBrO}_{3}$ or $\mathrm{NFT}$ for 13 Weeks

\begin{tabular}{|c|c|c|c|c|c|c|c|c|c|}
\hline & \multicolumn{2}{|c|}{ Control } & \multicolumn{2}{|c|}{1,500 ppm $\mathrm{KBrO}_{3}$} & \multicolumn{3}{|c|}{ 2,500 ppm NFT } \\
\hline & & & Number (\%) & \multirow[t]{2}{*}{$\begin{array}{l}\text { Mutation } \\
\text { frequencies } \\
\left(10^{-5}\right)\end{array}$} & Number (\%) & \multirow[t]{2}{*}{$\begin{array}{l}\text { Mutation } \\
\text { frequencies } \\
\left(10^{-5}\right)\end{array}$} & \multicolumn{2}{|c|}{ Number (\%) } & \multirow[t]{2}{*}{$\begin{array}{l}\text { Mutation } \\
\text { frequencies } \\
\quad\left(10^{-5}\right)\end{array}$} \\
\hline$N r f 2^{+/+}$ & Single bp & leletion & & & & & & & \\
\hline & Simple & $\mathrm{G}$ or $\mathrm{C}$ & $10(13.7)$ & $0.04 \pm 0.03$ & $24(12.8)$ & $0.11 \pm 0.07 *$ & 6 & (12.8) & $0.05 \pm 0.05$ \\
\hline & & $\mathrm{A}$ or $\mathrm{T}$ & $2(2.7)$ & $0.01 \pm 0.02$ & $13(7.0)$ & $0.05 \pm 0.04 *$ & 2 & $(4.3)$ & $0.01 \pm 0.02$ \\
\hline & In run & $\mathrm{G}$ or $\mathrm{C}$ & $20(27.4)$ & $0.09 \pm 0.05$ & 60 (32.1) & $0.27 \pm 0.09 * *$ & 22 & $(46.8)$ & $0.16 \pm 0.10$ \\
\hline & & $\mathrm{A}$ or $\mathrm{T}$ & $28(38.4)$ & $0.12 \pm 0.06$ & 63 (33.7) & $0.29 \pm 0.10^{* *}$ & 10 & (21.3) & $0.06 \pm 0.06$ \\
\hline & 2 to $1 \mathrm{~kb} \mathrm{c}$ & eletion ${ }^{a}$ & $1(1.4)$ & $0.00 \pm 0.01$ & $12(6.4)$ & $0.05 \pm 0.05^{*}$ & 0 & & 0 \\
\hline & Over $1 \mathrm{~kb}$ & deletionb & $12(16.4)$ & $0.05 \pm 0.03$ & $15(8.0)$ & $0.08 \pm 0.06$ & 4 & (8.5) & $0.02 \pm 0.03$ \\
\hline & Complex & & 0 & 0 & 0 & 0 & 1 & (2.1) & $0.00 \pm 0.01$ \\
\hline & Insertion & & 0 & 0 & 0 & 0 & 0 & & 0 \\
\hline & Base subs & itution & 0 & 0 & 0 & 0 & 2 & (4.3) & $0.01 \pm 0.03$ \\
\hline & Total & & 73 & 0.31 & 187 & 0.85 & 47 & & 0.33 \\
\hline \multirow{11}{*}{$N r f 2^{-/-}$} & Single $b p$ & leletion & & & & & & & \\
\hline & Simple & $\mathrm{G}$ or $\mathrm{C}$ & $13(28.3)$ & $0.09 \pm 0.07$ & $17(10.8)$ & $0.10 \pm 0.09$ & 5 & (7.0) & $0.03 \pm 0.05$ \\
\hline & & $\mathrm{A}$ or $\mathrm{T}$ & $1(2.2)$ & $0.00 \pm 0.01$ & $15(9.6)$ & $0.10 \pm 0.11 \dagger$ & 3 & $(4.2)$ & $0.02 \pm 0.02$ \\
\hline & In run & $\mathrm{G}$ or $\mathrm{C}$ & $6(13.0)$ & $0.04 \pm 0.03$ & $44(28.0)$ & $0.23 \pm 0.09 \dagger \dagger$ & 24 & $(33.8)$ & $0.12 \pm 0.07 \dagger$ \\
\hline & & $\mathrm{A}$ or $\mathrm{T}$ & $22(47.8)$ & $0.13 \pm 0.07$ & $50(31.8)$ & $0.31 \pm 0.13 \dagger$ & 20 & $(28.2)$ & $0.10 \pm 0.06$ \\
\hline & 2 to $1 \mathrm{~kb} \mathrm{c}$ & eletion ${ }^{a}$ & 0 & 0 & $19(12.1)$ & $0.13 \pm 0.09 \dagger \dagger$ & 3 & $(4.2)$ & $0.02 \pm 0.03$ \\
\hline & Over $1 \mathrm{~kb}$ & deletion $\mathrm{b}$ & $4(8.7)$ & $0.02 \pm 0.04$ & $11(7.0)$ & $0.05 \pm 0.07$ & 14 & (19.7) & $0.08 \pm 0.07$ \\
\hline & Complex & & 0 & 0 & 0 & 0 & 0 & & 0 \\
\hline & Insertion & & 0 & 0 & 0 & 0 & 1 & (1.4) & $0.01 \pm 0.02$ \\
\hline & Base subs & itution & 0 & 0 & $1(0.6)$ & $0.00 \pm 0.01$ & 1 & (1.4) & $0.00 \pm 0.01$ \\
\hline & Total & & 46 & 0.28 & 157 & 0.92 & 71 & & 0.36 \\
\hline
\end{tabular}

$* P<0.05$ vs. respective control group; ${ }^{* *} P<0.01$ vs. respective control group. $\dagger P<0.05$ vs. respective control group; $\dagger \dagger P<0.01$ vs. respective control group. aDeletion mutation of two or more but less than one thousand base pairs. bDeletion mutation of more than one thousand base pairs. 


\section{References}

1. Murata M, Midorikawa K, and Kawanishi S. Oxidative DNA damage and mammary cell proliferation by alcoholderived salsolinol. Chem Res Toxicol. 26: 1455-1463. 2013. [Medline] [CrossRef]

2. Rundhaug JE, and Fischer SM. Molecular mechanisms of mouse skin tumor promotion. Cancers (Basel). 2: 436-482. 2010. [Medline] [CrossRef]

3. Klaunig JE, Xu Y, Isenberg JS, Bachowski S, Kolaja KL, Jiang J, Stevenson DE, and Walborg EF Jr. The role of oxidative stress in chemical carcinogenesis. Environ Health Perspect. 106(Suppl 1): 289-295. 1998. [Medline] [CrossRef]

4. Saha SK, Lee SB, Won J, Choi HY, Kim K, Yang GM, Dayem AA, and Cho SG. Correlation between oxidative stress, nutrition, and cancer initiation. Int J Mol Sci. 18: 1544. 2017. [Medline] [CrossRef]

5. Okazaki K, Ishii Y, Kitamura Y, Maruyama S, Umemura T, Miyauchi M, Yamagishi M, Imazawa T, Nishikawa A, Yoshimura Y, Nakazawa H, and Hirose M. Dose-dependent promotion of rat forestomach carcinogenesis by combined treatment with sodium nitrite and ascorbic acid after initiation with N-methyl-N'-nitro-N-nitrosoguanidine: possible contribution of nitric oxide-associated oxidative DNA damage. Cancer Sci. 97: 175-182. 2006. [Medline] [CrossRef]

6. Umemura T, Kodama Y, Kurokawa Y, and Williams GM. Lack of oxidative DNA damage or initiation of carcinogenesis in the kidneys of male F344 rats given subchronic exposure to $\mathrm{p}$-dichlorobenzene (pDCB) at a carcinogenic dose. Arch Toxicol. 74: 54-59. 2000. [Medline] [CrossRef]

7. Kasai H, and Nishimura S. Formation of 8-hydroxydeoxyguanosine in DNA by oxygen radicals and its biological significance. In: Oxidative Stress: Oxidants and Antioxidants. H Sies. Academic Press, London. 99-116. 1991.

8. Michaels ML, Pham L, Cruz C, and Miller JH. MutM, a protein that prevents G.C-T-A transversions, is formamidopyrimidine-DNA glycosylase. Nucleic Acids Res. 19: 3629-3632. 1991. [Medline] [CrossRef]

9. Nakabeppu Y. Cellular levels of 8-oxoguanine in either DNA or the nucleotide pool play pivotal roles in carcinogenesis and survival of cancer cells. Int J Mol Sci. 15: 12543-12557. 2014. [Medline] [CrossRef]

10. Nohmi T, Kim SR, and Yamada M. Modulation of oxidative mutagenesis and carcinogenesis by polymorphic forms of human DNA repair enzymes. Mutat Res. 591: 60-73. 2005. [Medline] [CrossRef]

11. Ishidate M Jr, Sofuni T, Yoshikawa K, Hayashi M, Nohmi T, Sawada M, and Matsuoka A. Primary mutagenicity screening of food additives currently used in Japan. Food Chem Toxicol. 22: 623-636. 1984. [Medline] [CrossRef]

12. Ishidate $\mathrm{M} \mathrm{Jr}$, and Yoshikawa $\mathrm{K}$. Chromosome aberration tests with Chinese hamster cells in vitro with and without metabolic activation-a comparative study on mutagens and carcinogens. Arch Toxicol Suppl. 4: 41-44. 1980. [Medline] [CrossRef]

13. Hayashi M, Kishi M, Sofuni T, and Ishidate M Jr. Micronucleus tests in mice on 39 food additives and eight miscellaneous chemicals. Food Chem Toxicol. 26: 487-500. 1988. [Medline] [CrossRef]

14. Umemura T, Kitamura Y, Kanki K, Maruyama S, Okazaki K, Imazawa T, Nishimura T, Hasegawa R, Nishikawa A, and Hirose M. Dose-related changes of oxidative stress and cell proliferation in kidneys of male and female F344 rats exposed to potassium bromate. Cancer Sci. 95: 393-398. 2004. [Medline] [CrossRef]

15. Ballmaier D, and Epe B. Oxidative DNA damage induced by potassium bromate under cell-free conditions and in mammalian cells. Carcinogenesis. 16: 335-342. 1995. [Medline] [CrossRef]

16. Umemura T, Sai K, Takagi A, Hasegawa R, and Kurokawa $\mathrm{Y}$. A possible role for cell proliferation in potassium bromate $\left(\mathrm{KBrO}_{3}\right)$ carcinogenesis. J Cancer Res Clin Oncol. 119: 463-469. 1993. [Medline] [CrossRef]

17. Kasai H, Nishimura S, Kurokawa Y, and Hayashi Y. Oral administration of the renal carcinogen, potassium bromate, specifically produces 8-hydroxydeoxyguanosine in rat target organ DNA. Carcinogenesis. 8: 1959-1961. 1987. [Medline] [CrossRef]

18. Murata M, Bansho Y, Inoue S, Ito K, Ohnishi S, Midorikawa $\mathrm{K}$, and Kawanishi S. Requirement of glutathione and cysteine in guanine-specific oxidation of DNA by carcinogenic potassium bromate. Chem Res Toxicol. 14: 678-685. 2001. [Medline] [CrossRef]

19. Umemura T, Kanki K, Kuroiwa Y, Ishii Y, Okano K, Nohmi $\mathrm{T}$, Nishikawa $\mathrm{A}$, and Hirose $\mathrm{M}$. In vivo mutagenicity and initiation following oxidative DNA lesion in the kidneys of rats given potassium bromate. Cancer Sci. 97: 829-835. 2006. [Medline] [CrossRef]

20. IARC Working Group on the Evaluation of the Carcinogenic Risk to Humans Nitrofurantoin. IARC Monographs on the Evaluation of the Carcinogenic Risks to Humans, Vol. 50. Lyon. 211-231. 1990.

21. Chung MC, Bosquesi PL, and dos Santos JL. A prodrug approach to improve the physico-chemical properties and decrease the genotoxicity of nitro compounds. Curr Pharm Des. 17: 3515-3526. 2011. [Medline] [CrossRef]

22. Boelsterli UA, Ho HK, Zhou S, and Leow KY. Bioactivation and hepatotoxicity of nitroaromatic drugs. Curr Drug Metab. 7: 715-727. 2006. [Medline] [CrossRef]

23. Bartel LC, Montalto de Mecca M, and Castro JA. Nitroreductive metabolic activation of some carcinogenic nitro heterocyclic food contaminants in rat mammary tissue cellular fractions. Food Chem Toxicol. 47: 140-144. 2009. [Medline] [CrossRef]

24. Kijima A, Ishii Y, Takasu S, Matsushita K, Kuroda K, Hibi D, Suzuki Y, Nohmi T, and Umemura T. Chemical structure-related mechanisms underlying in vivo genotoxicity induced by nitrofurantoin and its constituent moieties in gpt delta rats. Toxicology. 331: 125-135. 2015. [Medline] [CrossRef]

25. Lee JS, and Surh YJ. Nrf2 as a novel molecular target for chemoprevention. Cancer Lett. 224: 171-184. 2005. [Medline] [CrossRef]

26. Jaiswal AK. Regulation of genes encoding $\mathrm{NAD}(\mathrm{P})$ H:quinone oxidoreductases. Free Radic Biol Med. 29: 254 262. 2000. [Medline] [CrossRef]

27. Yokoo Y, Kijima A, Ishii Y, Takasu S, Tsuchiya T, and Umemura T. Effects of Nrf2 silencing on oxidative stressassociated intestinal carcinogenesis in mice. Cancer Med. 5: 1228-1238. 2016. [Medline] [CrossRef]

28. Umemura T, Kuroiwa Y, Kitamura Y, Ishii Y, Kanki K, Kodama Y, Itoh K, Yamamoto M, Nishikawa A, and Hirose M. A crucial role of Nrf2 in in vivo defense against oxidative damage by an environmental pollutant, pentachlorophenol. 
Toxicol Sci. 90: 111-119. 2006. [Medline] [CrossRef]

29. Tasaki M, Kuroiwa Y, Inoue T, Hibi D, Matsushita K, Kijima A, Maruyama S, Nishikawa A, and Umemura T. Lack of $n r f 2$ results in progression of proliferative lesions to neoplasms induced by long-term exposure to non-genotoxic hepatocarcinogens involving oxidative stress. Exp Toxicol Pathol. 66: 19-26. 2014. [Medline] [CrossRef]

30. Kitamura Y, Umemura T, Kanki K, Kodama Y, Kitamoto S, Saito K, Itoh K, Yamamoto M, Masegi T, Nishikawa $\mathrm{A}$, and Hirose M. Increased susceptibility to hepatocarcinogenicity of Nrf2-deficient mice exposed to 2-amino3-methylimidazo[4,5-f]quinoline. Cancer Sci. 98: 19-24. 2007. [Medline] [CrossRef]

31. Kanki K, Umemura T, Kitamura Y, Ishii Y, Kuroiwa Y, Kodama Y, Itoh K, Yamamoto M, Nishikawa A, and Hirose M. A possible role of nrf2 in prevention of renal oxidative damage by ferric nitrilotriacetate. Toxicol Pathol. 36: 353-361. 2008. [Medline] [CrossRef]

32. Nohmi T, Suzuki T, and Masumura K. Recent advances in the protocols of transgenic mouse mutation assays. Mutat Res. 455: 191-215. 2000. [Medline] [CrossRef]

33. Matsushita K, Ishii Y, Takasu S, Kuroda K, Kijima A, Tsuchiya T, Kawaguchi H, Miyoshi N, Nohmi T, Ogawa K, Nishikawa A, and Umemura T. A medium-term gpt delta rat model as an in vivo system for analysis of renal carcinogenesis and the underlying mode of action. Exp Toxicol Pathol. 67: 31-39. 2015. [Medline] [CrossRef]

34. Itoh $\mathrm{K}$, Chiba $\mathrm{T}$, Takahashi $\mathrm{S}$, Ishii $\mathrm{T}$, Igarashi $\mathrm{K}$, Katoh Y, Oyake T, Hayashi N, Satoh K, Hatayama I, Yamamoto $\mathrm{M}$, and Nabeshima Y. An Nrf2/small Maf heterodimer mediates the induction of phase II detoxifying enzyme genes through antioxidant response elements. Biochem Biophys Res Commun. 236: 313-322. 1997. [Medline] [CrossRef]

35. Kurokawa Y, Maekawa A, Takahashi M, and Hayashi Y.
Toxicity and carcinogenicity of potassium bromate-a new renal carcinogen. Environ Health Perspect. 87: 309-335. 1990. [Medline]

36. French JE. Toxicology and carcinogenesis studies of nitrofurantoin (CAS NO. 67-20-9) in F344/N rats and B6C3F mice (feed studies). 1989, from National Toxicology Program website: https://ntp.niehs.nih.gov/ntp/htdocs/lt_rpts/ tr341.pdf.

37. Umemura T, Kai S, Hasegawa R, Kanki K, Kitamura Y, Nishikawa A, and Hirose M. Prevention of dual promoting effects of pentachlorophenol, an environmental pollutant, on diethylnitrosamine-induced hepato- and cholangiocarcinogenesis in mice by green tea infusion. Carcinogenesis. 24: 1105-1109. 2003. [Medline] [CrossRef]

38. Luan Y, Suzuki T, Palanisamy R, Takashima Y, Sakamoto H, Sakuraba M, Koizumi T, Saito M, Matsufuji H, Yamagata K, Yamaguchi T, Hayashi M, and Honma M. Potassium bromate treatment predominantly causes large deletions, but not GC>TA transversion in human cells. Mutat Res. 619: 113-123. 2007. [Medline] [CrossRef]

39. Tsuchiya T, Kijima A, Ishii Y, Takasu S, Yokoo Y, Nishikawa A, Yanai T, and Umemura T. Role of oxidative stress in the chemical structure-related genotoxicity of nitrofurantoin in Nrf2-deficient gpt delta mice. J Toxicol Pathol. 31: 169-178. 2018.

40. Il'yasova D, Scarbrough P, and Spasojevic I. Urinary biomarkers of oxidative status. Clin Chim Acta. 413: 14461453. 2012. [Medline] [CrossRef]

41. Di Minno A, Turnu L, Porro B, Squellerio I, Cavalca V, Tremoli E, and Di Minno MND. 8-hydroxy-2-deoxyguanosine levels and cardiovascular disease: a systematic review and meta-analysis of the literature. Antioxid Redox Signal. 24: 548-555. 2016. [Medline] [CrossRef] 